\title{
Green Banking : One Effort To Achieve The Principle Of Good Corporate Governance (GCG)
}

\author{
Fia Dialysa \\ Sekolah Tinggi Ilmu Ekonomi (STIE) EKUITAS \\ Email : fdialysa@yahoo.com/fdialysa@gmail.com
}

\begin{abstract}
Environmental damage that occurs in most of the Earth causing environmental movement nowadays in various fields with the term green, eco. One of them is in banking.

Implementation of green banking holds the principle of sustainable development that development should have a balance on three viewpoints (Triple Bottom Line), they are Profit (Economy), People (Social) and Planet (Safe Environment). Business sustainability in the future must be achieved, the value of the company increase and grow rapidly also it must minimize the risk of environmental damage effectively and efficiently. (under the rules of Bank Indonesia refer to law no.32/2009 about the protection and management of the environment).(www.bi.go.id )

Principles and purposes of green banking has similarities with the purposes and principles of Good Corporate Governance (GCG) that had already done (under the rules of Bank Indonesia no. 8/4/PBI/2006 on $30^{\text {th }}$ Januari 2006) which emphasizes the active co-operation between companies and stakeholders in creating wealth through good corporate governance in order to achieve a sustainable business. Through this similarity, the banking company can make a Positioning of their products in society becomes more precise through the principles of eco or green to support the success of Good Corporate Governance (GCG) by doing recycle program, less paper office program, energy savings, green investment, and green financing.

The purpose of this paper is to emphasize the importance of green banking as an effort to achieve the principle of Good Corporate Governance (GCG). This paper is the type of qualitative. The data will collected through descriptive analysis method, literature study and theoretical analysis.

The result of this paper is intended for Indonesian society, especially in the banking sector in order to create a sustainable business in the green banking industry towards ASEAN Economic Community (AEC) 2015.
\end{abstract}

Keywords: Green Banking; Good Corporate Governance (GCG); Sustainability.

\section{INTRODUCTION}

Global warming is a global issue that calls for a global response. It refers to the increased temperature of Earth's surface, including land, water and near-surface air. The rapid change in climate will probably be too great to allow many eco systems to suitably adapt, since the changes have direct impact on bio diversity, agriculture, forestry, dry land, water resources and human health. But while the effects of climate change are increasingly a risk to the health, economy and the environment of the country, economists are also recognizing that there are financial rewards from controlling climate change and developing a low carbon economy.(www.greeneconomy.co.id ).
In the modern business environment, sustainable development is largely achieved through the implementation of the concept of the green economy, both at the global and national as well as at the corporate level. (Vareen, 2008).

Ahead of the implementation some state-owned banks of neighboring countries have made preparation. Sustainable development should have a balance on three viewpoints (Triple Bottom Line), they are Profit (Economy), People (Social) and Planet (Safe Environment). (Carter and Rogers, 2008).

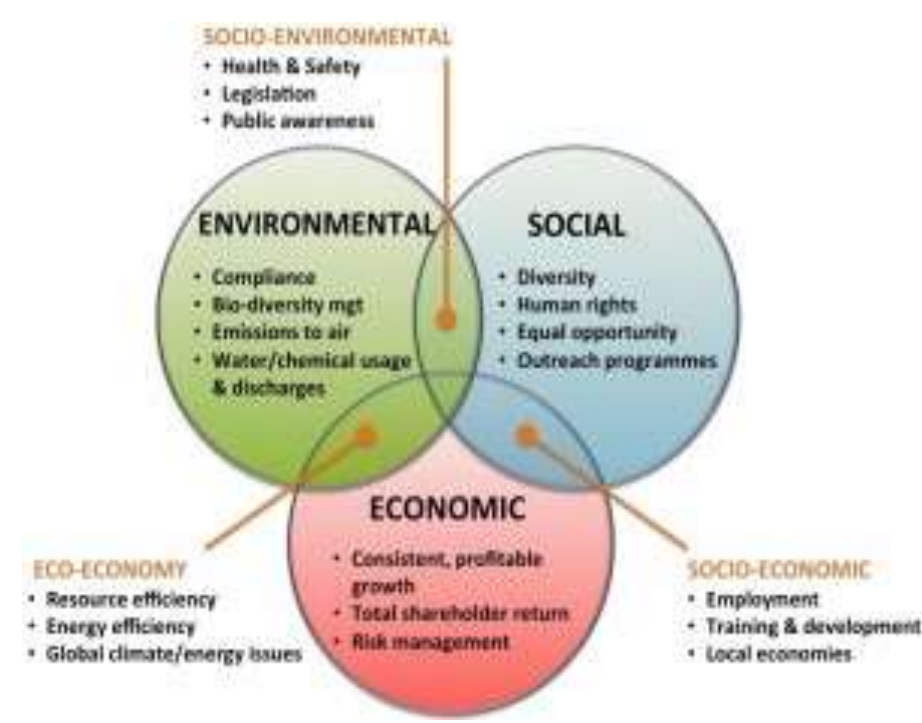

Figure 1 The Triple Bottom Line

Source: Carter and Rogers, 2008

It is the adoption of this Triple Bottom Line approach that characterises the development of a sustainable enterprise. This Triple Bottom Line is often summarised as a co-ordinated business strategy that ensure that the enterprise aligns its goals with positive outcomes for People (social), Profit (economic) and the Planet (environmental).

Banking sector plays a crucial and decisive role in promoting environmentally sustainable and socially responsible investments.(Jeucken, 2001). Banks can provide important leadership for the required economic transformation that will provide new opportunities for financing and investment policies as well as portfolio management for the creation of a strong and successful low carbon economy. However, there is general lack of adequate awareness on the above issues and hence there is urgent need to promote certain urgent measures for sustainable development. (www.globalreporting.org ). 
Although banks are considered environment friendly and do not impact the environment greatly through their own 'internal' operations, the 'external' impact on the environment through their customers activities is substantial.(Starogiannis, 2006).

\section{Green Banking}

The banking sector can play an intermediary role between economic development and environmental protection, for promoting environmentally sustainable and socially responsible investment. (Benedikter, 2011). "Green banking" refers to the banking business conducted in such areas and in such a manner that helps the overall reduction of external carbon emission and internal carbon footprint. (Green, 1989).

Financial Services Authority needs to immediately formulate a blueprint of national banks to engage various stakeholders. One of the reasons why the banking consolidation agenda cannot be realized until today, is the absence of a national banking blueprint. Bank Indonesia already give some regulations about the green banking concepts (www.bi.go.id ) :

1. Bank should consider environment protection in assessing asset quality (PBI No. 14/15/PBI/2012).

2. Bank should increase productive loans and access loan for Small Medium Enterprises PBI (No.14/26/PBI/2012 and PBI No.14/22/PBI/2012).

The functionality and sound performance of traditional banking is in question, due to the credit crisis, requiring a comprehensive incorporation of ethical values and principles into banking practices). (Monte, 2010).

Some green banking initiatives worldwide include (www.banktrack.org):

-Paperless statements, bills and annual reports.

-Donations to conservation charities as an incentive for choosing green products.

-Special line of credit to homeowners for investment in energy-efficient upgrades.

Listed below are some proactive initiatives of banks globally (www.banktrack.org):

-Canadian banks have adopted the Equator Principles, a set of globally recognized, voluntary guidelines established to assess and manage social and environmental risk in project financing.

-At the end of 2010, green credit issued by Bank of China exceeded RMB 190 billion with new issuances up by more than 40 billion.

-At the end of 2011, China Development Bank had lent 658 billion Yuan to energy-saving, emission-reducing projects, accounting for $12.7 \%$ of the bank's total outstanding loans.

-The State Bank of India has introduced "green channel counters" and "no queue banking" in over 5,000 branches across India, doing away with deposit slips.

\section{Good Corporate Governance (GCG)}

Good corporate governance (GCG) is one of the bank strategy to ensures that the business environment is fair and transparent and that companies can be held accountable for their actions. It is a series of mechanisms that can protect minority parties (outside investors/minority shareholders) from expropriation by managers and controlling shareholders (insider) with emphasis on legal mechanisms (Macey, 2003).

Good Corporate Governance (GCG) is defined as a pattern of relationships, systems, and processes used by the organs of the company (Board of Directors, Board of Commissioners, GMS) to provide added value to shareholders on an ongoing basis in the long term, with due regard to the interests of other stakeholders, based on laws and norms that applies (Klapper, 2002).

In Asia, including Indonesia, the concept of Good Corporate Governance (GCG) began much discussed in mid1997, when the crisis struck the region. Economic crisis and financial crisis in 1997 -1998 made the company unableto pay debts to the bank and bonds in foreign currencies both principal and interest. Companies that are not capable of experiencing the problem cannot afford to pay the debt so that its value has decreased. The impact of the crisis showed that many companies could not survive. (www.banktrack.org )

One of the reason is because the growth that was achieved was not built on a solid foundation according to the principles of good corporate governance. In other words, the bad practice of GCG has made the companiesfailed in facing the crisis. (Sulistyanto dan Wibisono, 2003).

Conversely, weak corporate governance leads to waste, mismanagement, and corruption. It is also important to remember that although corporate governance has emerged as a way to manage modern joint stock corporations it is equally significant in state-owned enterprises, cooperatives, and family businesses. Regardless of the type of venture, only good governance can deliver sustainable good business performance.

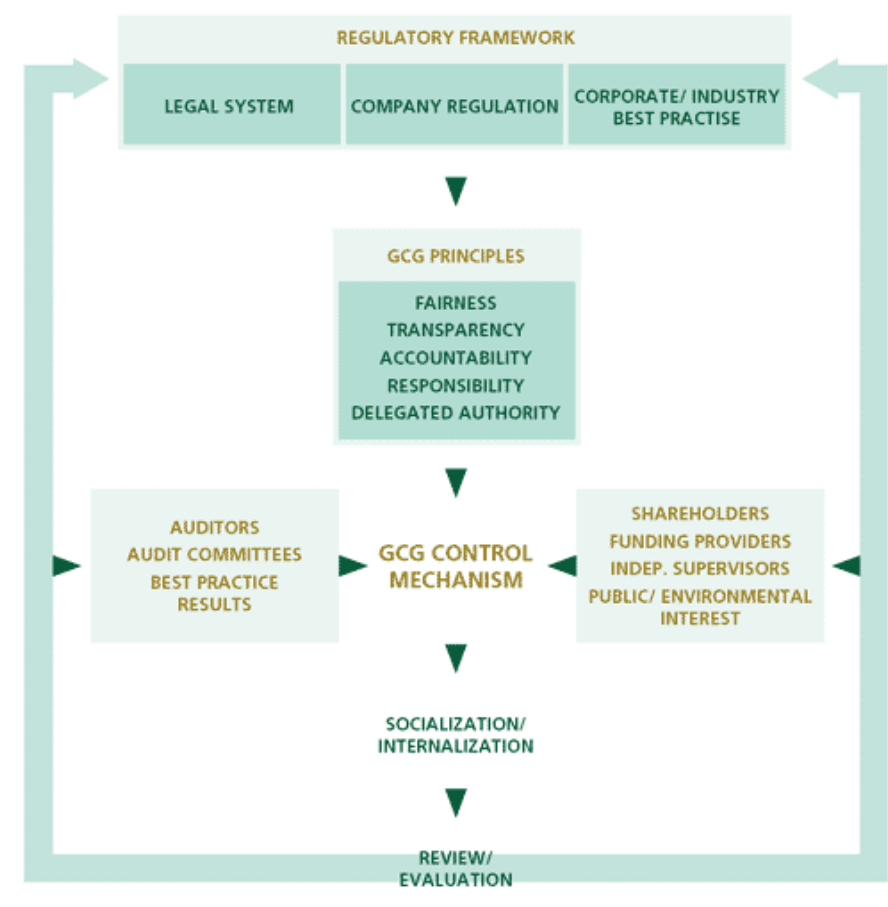

Figure 2 Good Corporate Governance (GCG) Framework

\section{Source:The Jakarta Consulting Group, 2002}

The implementation of Good Corporate Governance (GCG) adheres to Bank Indonesia Regulation number 
8/4/PBI/2006 regarding Good Corporate Governance for Public Banks and its amendments. Also State-Owned Enterprise (SOE) Minister of the Republic of Indonesia released a Ministerial Decision on Implementation of SOE that is "Keputusan Menteri BUMN KEP-117/MMBU/2001" about GCG practices at SOE. (www.bi.go.id ). In the minister's decision was conveyed that each state must implement a consistent and GCG as a foundation or made operational. GCG implementation in companies implemented based on the principles that have been established.

In general GCG implementation consists of five basic principles, those are: transparency, accountability, responsibility, independency, and fairness that can called as TARIF to make it easier. (Daniri, 2005)

1.Transparency. Transparency can be defined as the disclosure of information, both in the decision making process as well as in revealing material and relevant information about the company.

2. Accountability. Accountability is the clarity of function, structure, systems of the company so that the company management is effectively implemented.

3. Responsibility. Responsibility is conformity (compliance) in the company management towards a healthy corporate principles and applicable legislation. Regulations that apply here include those relating to tax matters, industrial relations, environmental protection, safety, payroll standards, and healthy competition.

4. Independency. Independence is a state where the company is managed professionally without conflict of interest and influence/pressure from any party that is not in compliance with applicable laws and principles of a healthy corporation.

5. Fairness. Fairness can be defined as a fair and equal treatment in fulfilling stakeholders' rights arising under the agreement and applicable laws and regulations. Fairness also includes a clear sign of investor rights, legal system and enforcement of regulations to protect investors' rights, especially minority shareholders of the various forms of cheating.

Daniri (2005) explains about the benefits of GCG implementation. Good Corporate Governance (GCG) includes :

1. Reduce the agency cost, which is a cost to be borne by shareholders as a result of the delegation of authority to management. These costs may include losses suffered by the company as a result of abuse of authority (wrong-doing), or in the form of oversight costs incurred to prevent it.

2. Reduce the cost of capital (cost of capital). As a result of good corporate management, it causes the interest rate on the funds or resources borrowed by the company gets smaller as the decline in the firm's risk level.

3 . Increase the value of company stock while increasing the company's image in the public for long term.

4. Create supports for stakeholders in the enterprise environment is the existence of the company and the various strategies and policies pursued by the company, because generally they received assurances that they also can get the maximum benefits of all the actions and the operations of enterprises in creating wealth and prosperity.

Benefits of Good Corporate Governance is not just for today but also for long term, it can become the main supporting pillar of the company development as well as the pillars of global competition winners.(Naja, 2007).
At the moment, governance is different in every country, depending on culture and many other factors, but there is a global trend for standardization.

The OECD Principles cover five basic subjects: 1)protection of shareholders rights; 2 ) equitable treatment of shareholders, including full disclosure of material information and the prohibition of abusive self-dealing and insider trading; 3)recognition and protection of the exercise, of the rights of stakeholders as established by law and encouragement of co-operation between corporations and stakeholders in creating wealth and jobs in enterprise; 4)timely and accurate disclosure and transparency with respect to matters material to company performance, ownership and governance, which should include an annual audit conducted by an independent auditor; and 5)a framework of corporate governance ensuring strategic guidance of the company and effective monitoring of its management by the board of directors as well as the board's accountability to the company and its shareholders.(OECD, 2010).

Corporate governance is the system by which business corporations are directed and controlled. The corporate governance structure specifies the distribution of rights and responsibilities among different participants in the corporation, such as the board, the manages, the shareholders and other stakeholders, and spells out the rules and procedure for making decisions on corporate affairs. By doing this, it also provides the structure through which the company objectives are set, and the means of attaining those objectives and monitoring performance. (Suprayitno, 2004).

Australian Stock Exchange (ASX) : Corporate Governance is the system by which companies are directed and managed. It influences how the objectives of the company set and achieved, how risk is monitored and assessed, and how performance is optimized.(www.asx.co.id )

Principles and purposes of green banking has similarities with the purposes and principles of Good Corporate Governance (GCG) that had already done (under the rules of Bank Indonesia no. 8/4/PBI/2006 on $30^{\text {th }}$ Januari 2006) which emphasizes the active co-operation between companies and stakeholders in creating wealth through good corporate governance in order to achieve a sustainable business in the sector of Business Ethics and Practices/the responsibility.

\section{Practical Implication}

This research is expected to contribute in providing an overview of the implementation of Good Corporate Governance (GCG) in Indonesia which can be used by green banking concepts and reinforcing previous studies regarding the green banking and Good Corporate Governance (GCG).

\section{IMPLEMENTATION OF GREEN BANKING}

Hopefully, 2015 is the right moment to begin to realize the banking consolidation agenda. The four State-Owned Banks, PT. Bank Mandiri Tbk, PT. Bank Rakyat Indonesia Tbk, PT. Bank Negara Indonesia Tbk, and PT. Bank BTN Tbk need to be a pioneer in the banking consolidation agenda. The four banks are located in the upper caste in the Indonesian banking industry. The consolidation of the four large state-owned banks is expected to be followed by a Public Private Banks in Indonesia. 
They have in place and has been implementing Good Corporate Governance (GCG) principles in company operations since 2001. Since then, reviews and adjustments have been continuously undertaken to keep them in line with the development of policy, regulations and both internal and external conditions.

Apart from Bank Indonesia Regulation number 8/4/PBI/2006 regarding Good Corporate Governance for Public Banks, the main reference for the implementation of Good Corporate Governance (GCG) are :

1. Bank BNI is the Capital Market Act, Limited Liability Company Act and State-Owned Enterprise Act. BNI already involved in some programme such as, financing renewable energy, participating in carbon trading, investing in geothermal power plants, utilizing the abundant water resources, services for eco-friendly project, reducing paper use, saving from lamp, rainwater harvesting etc. (www.bni.co.id )

2. Bank BRI also active in paper less program, green portofolio, saving electricity, encouraging sustainable agribusiness and article on the debtor project that the project should not damage the environment. (www.bri.co.id )

3. Bank BTN focus in green loan, paper less, recycle program, and environmental development program.(www.btn.co.id )

4. Bank Mandiri also active in paper less program, green portofolio, saving from lamp, and give loans to Agence Francaise de Development (AFD) for hydropower project during period 2010-2012. (www.mandiri.co.id ).

All the programs followed by another banks to join in develop the green concept.

\section{SUSTAINABILITY THROUGH GREEN ECONOMY}

In a recent year, sustainability business must be achieved especially in tight competition. Green action concept is one of the builder in green economy era. Environment responsibility is the mission of the green actions which is have the similarities with the principle of Good Corporate Governance (GCG) (responsibility principle). (Daniri, 2005).

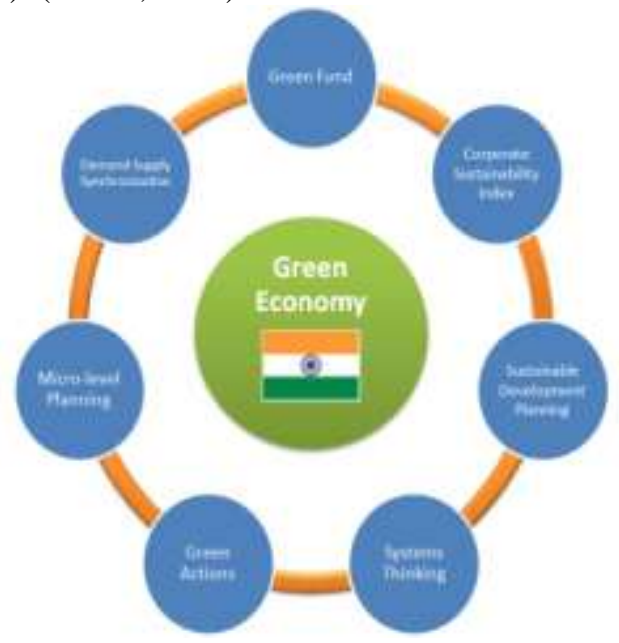

Figure 3 Green Economy Framework

\section{Source: United Nations Environment Programme} (UNEP), 2011
Basically Green banking avoids as much paper work as possible and rely on online/ electronic transactions for processing. Less paperwork means less cutting of trees. It also involves creating awareness to banking business people about environmental and social responsibility enabling them to do an environmental friendly business practice. (www.greeneconomy.co.id ).

The value proposition for corporations to go green includes many of the same issues as that for individual consumers but on a much large scope and with additional concerns. Corporations may share a desire to reduce carbon footprint and enhance security by eliminating paper waste, but they are also extremely concerned with eliminating or decreasing errors due to manual processing and with creating a profitable bottom line.

For these reasons and more, corporations are actively pursuing green programs, many companies are taking active steps to reduce waste, implement sustainability measures and increase profitability by going green. (Green, 1989).

\section{RESEARCH METHODOLOGY}

This research aims to examine the green banking as one effort to achieve the principle of Good Corporate Governance (GCG). The research methodology used in this study is based on secondary data. The study examines major aspects concerned with the Green Banking and Good Corporate Governance (GCG). This paper is the type of qualitative. The data will collected through descriptive analysis method, literature study and theoretical analysis.

\section{CONCLUSION}

The green banking concept is a part of the Good Corporate Governance (GCG). The similarity is in the principle of responsibility. So, the environmental sustainability can be properly maintained.

Green banking activities are :

1. Go Online, online banking helps in additional conservation of energy and natural resources (paying bills online, remote deposit, and online fund transfers). It creates savings from less paper, less energy, and less expenditure of natural resources from banking activities.

2. Banks can also make a feasibility study to make rain water harvesting mandatory in all the Bank's owned premises.

3. Use Green Credit Cards, some of the banks introduced Green Credit Card. The benefit of using a green credit card is that banks will donate funds to an environment-friendly non-profit organization

4. Save Paper/paper less, bank should purchase recycled paper products with the highest post- consumer waste content possible.

5. The Soft Loan Credit, bank gives some credit with the long terms of payment and low interest.

6. Saving from lamp, saving energy, and saving electricity.

\section{REFERENCES}

Benedikter, R. (2011). Answers to the Economic Crisis: Social Banking and Social Finance, Spice Digest New York: Springer.

Carter, R. Craig. \& Rogers, S. Dale. (2008). A framework of sustainable supply chain management: moving toward 
new theory, International Journal of Physical Distribution \& Logistics Management, Vol. 38 Iss: 5

Daniri, Mas Ahmad. (2005). Good Corporate Governance Konsep dan Penerapannya dalam Konteks Indonesia.JakartaPusat:Ray Indonesia.

Green, C. F. (1989).Business Ethics in Banking. Journal of Business Ethics 8.8:631-634

Jeucken, M. (2001). Sustainable Finance and Banking, The finance Sector and the Future of the Planet. London, Earthscan.

Kasmir. (2003) Bank dan Lembaga Keuangan Lainnya. Edisi Enam.Jakarta: Raja Grafindo Persada.

Klapper, Leora F. and Inessa Love. (2002). Corporate Governance, Investor Protection, and Performance in Emerging Markets. World Bank Policy Research Working Paper 2818

Macey, Jonathan R. and O'hara. (2003). The Corporate Governance of Banks. Economic Policy Review FRBNY

Mukherjee, R. (2010). SBI launches green policy for paperless banking, Financial Chronicle, August 27.

Monte, L. (2010). It's Times for Green Banking, Business Standard, May 21

Naja, H.R. Daeng. (2007). Good Corporate Governance pada Lembaga Perbankan. Yogyakarta: Medpress (Anggota IKAPI)

OECD (Organisation for Economic Co-operation and Development). (1999). OECD Principles of Corporate Governance. OECD Publications Service. France: 9-19.

Sarita, B. (2012). The role of green banking in sustainable growth, International Journal of Marketing, Financial services \& Management research, Vol.1

Starogiannis, D. (2006). What is Environmental Responsibility of Banks. UNEP FI Conference, June

Sulistyanto, H. Sri, dan Wibisono, H. (2003). Good Corporate Governance: Berhasilkah Diterapkan di Indonesia. Jurnal Widya Warta, No.2 Tahun XXVI/Juli 2003, ISSN: 0854-1981. Semarang: Fakultas Ekonomi Unika Soegijapranata

Suprayitno, G. et al. (2004). Komitmen Menegakkan Good Corporate Governance.Jakarta:

The Indonesian Institute for Corporate Govenance.

The Jakarta Consulting Group, 2002

Vareen, R. (2008). A Green Dream, 4P's Business and Marketing.

Electronic Sources :

http://www.btn.co.id//

http://www.bni.co.id//

http://www.mandiri.co.id//

http://www.bri.co.id//

www.bi.go.id

www.unep.org

www.iced.or.id

www.greeneconomy.co.id

www.globalreporting.org

www.asx.co.id

www.banktrack.org 